\title{
Identifying the Entrepreneurship Characteristics of the Oil Palm Community Plantation Farmers in the Riau Area
}

\author{
Brilliant Asmitand Deddy P. Koestindartoto \\ School of Business and Management, Institut Teknologi Bandung (SBM-ITB)
}

\begin{abstract}
Oil palm is an essential and strategic commodity in the Riau area because of its considerable role in supporting the peoples' economy, especially for plantation farmers. Oil palm plantation activities have brought economic impacts to society there, both for the people who are directly involved with the plantations and for their surrounding communities. This regional advantage is a facility for farmers to be able to develop their farms as plantations. The aims of this research are to identify the entrepreneurship characteristics of the oil palm farmers, and also to identify the entrepreneurship characteristics that differentiate the farmers, as seen from their business' achievements. The research used a grounded theory approach to identify the characteristics of oil palm farmers systematically. The sampling method used for the research was theoretical sampling, which is data gathering driven by the concepts derived from the theory of previous entrepreneurship characteristics studies. The research object is the oil palm farmers in Riau, Indonesia. The results of the analysis identified the entrepreneurship characteristics of the oil palm farmers, they are growth oriented, risk-taking, innovative, with a sense of personal control, self confident, and cooperative. But, among the characteristics, only the characteristic of their cooperation did not differentiate the oil palm farmers in the achievement of their business activities.
\end{abstract}

\begin{abstract}
Abstrak: Kelapa sawit merupakan komoditas penting dan strategis di daerah Riau karena peran besarnya meningkatkan perekonomian rakyat, khususnya petani kelapa sawit. Kegiatan perkebunan kelapa sawit membawa dampak ekonomi kepada masyarakat, baik untuk orang-orang yang terlibat langsung dengan kegiatan perkebunan maupun masyarakat sekitar. Keunggulan daerah ini merupakan fasilitas bagi petani untuk dapat mengembangkan usaha pertaniannya sebagai pemilik kebun. Tujuan dari penelitian ini adalah untuk mengidentifikasi karakter kewirausahaan dari petani kelapa sawit, mengidentifikasi karakteristik kewirausahaan yang membedakan antara petani dilihat dari pencapaian bisnis mereka. Penelitian menggunakan pendekatan grounded theory untuk mengidentifikasi karakteristik petani kelapa sawit secara sistematis. Metode sampling yang digunakan adalah sampling teoritis, yaitu pengumpulan data yang didorong oleh konsep berasal dari teori karakter kewirausahaan dari penelitian sebelumnya. Objek penelitian adalah pemilik kebun kelapa sawit di Daerah Riau. Hasil analisis mengidentifikasi karakteristik kewirausahaan petani sawit yaitu berorientasi pada pertumbuhan, pengambil risiko, inovatif, rasa akan kontrol pribadi, kepercayaan diri, dan bekerjasama. Hanya karakteristik kerjasama yang tidak membedakan petani kelapa sawit dilihat dari prestasi kegiatan bisnis.
\end{abstract}

Keywords: entrepreneurship characteristic; farm entrepreneurship; oil palm

JEL classification: J23; L26

* Corresponding author's e-mail: brilliant.asmit@sbm-itb.ac.id

ISSN: $1141-1128$

http://journal.ugm.ac.id/gamaijb 


\section{Introduction}

Oil palm (Elaeis Guineensis) is an essential and strategic commodity in Riau because of its role in supporting and providing the peoples' economy there, especially for the oil palm plantation farmers. This is quite reasonable because Riau is suitable and has potential for the development of plantation agriculture. Compared to other potential plantation commodities in Riau, the development of oil palm is increasing year by year, while the areas planted with rubber and coconut are decreasing. Increasing oil palm plantation areas, with land conversion from other commodities to oil palm, shows the public's interest is still quite high for oil palm farming activities. Syahza (2012) said that the development of oil palm plantations in Riau was quite reasonable because it provided enormous economic dimensions, especially to the regional economy. This contributional ability is reflected in the labor absorption and revenue assurance.

Based on data from the Plantations Service of Riau province (2012), the oil palm area increased significantly from 2000's figure of 966,786 ha of oil palm plantations to 2,258,553 ha at the end of 2011, and made Riau the largest area of oil palm plantations in Indonesia. The expansion of the plantation area was followed by an increase in the production of oil palm Fresh Fruit Bunches (FFB), in 2000 the production from the oil palm plantations was $1,792,481$ tons and in 2011 it reached 7,047,221 tons. The potential of the oil palm plantations owned by the community has not yet been fulfilled. Table

Figure 1. Area Development of Three Largest Plantation Commodities in Riau 20072011

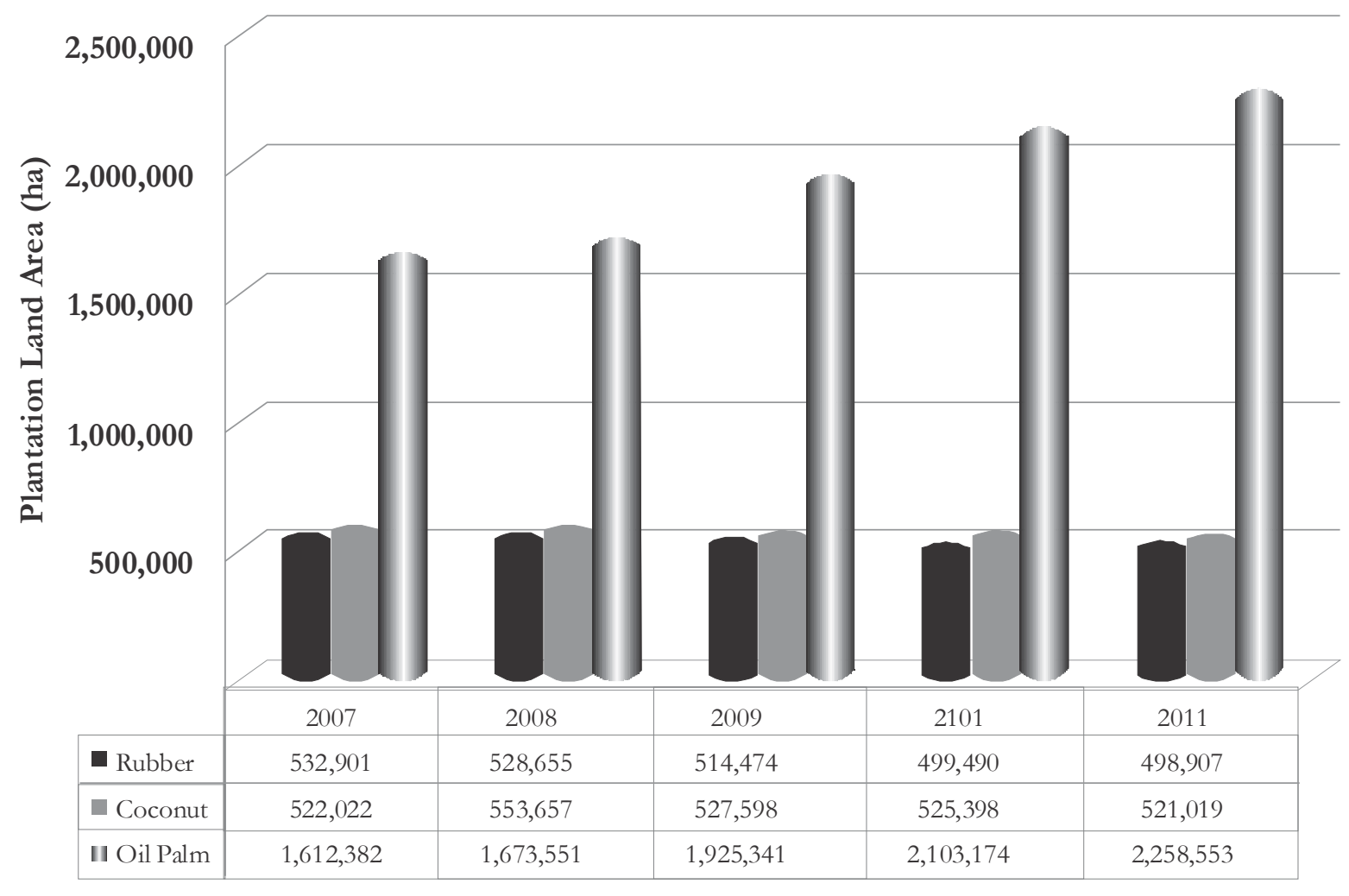


1 shows the production from community oil palm plantations was lower than that of privately owned oil palm plantations even though the area of the community plantations is larger. From annual reports by the Plantation Service of Riau (2012), the productivity of productive oil palm land in Riau is 3.97 tons/ha. The average productivity from the community oil palm plantations is 3.6 tons/ ha whereas the private oil palm plantations are higher, at 4.36 tons/ha. Moreover, the average oil palm productivity of Indonesia (3.8 tons/ha), is lower than that of Malaysia (4.6 tons/ha) and is very far from the potential productivity which could be achived, (7 tons/ha, according to the Coordinating Min- istry of Economic Affairs 2011). It needs the farmers' role as the community plantation owners to be examined, to fulfill the potential of the oil palm plantations.

The strategy of implementing MP3EI is done by integrating three main elements, one of them is strengthening the human resources capabilities to support the main program's development in any economic corridor. The success of the oil palm plantations' development in Riau will support the success of the MP3EI program in the Sumatran corridor. Fulfilling the potential of the oil palm commodity depends on the oil palm farmers as the farms' business owners.

\section{Table 1.Total Area and Production of Oil Palm Plantations in Each District in Province} of Riau year 2011

\begin{tabular}{lrrrr}
\hline \multicolumn{1}{c}{ District/City } & \multicolumn{2}{c}{ Land Area(ha) } & \multicolumn{3}{c}{ Production(ton) } \\
\hline Community Plantations & $\mathbf{1 , 2 0 5 , 4 9 8}$ & $\mathbf{( 5 3} \%)$ & $\mathbf{3 , 1 7 4 , \mathbf { 1 7 6 }}$ & $\mathbf{( 4 5 \% )}$ \\
- Kampar & 159,964 & 453,125 & \\
- Rokan Hulu & 208,056 & 486,055 & \\
- Pelalawan & 116,057 & 431,931 & \\
- Indragiri Hulu & 56,886 & 179,511 & \\
- Kuantan Singingi & 68,986 & 181,053 & \\
- Bengkalis & 132,384 & 277,099 & \\
- Rokan Hilir & 157,588 & 450,058 & \\
- Dumai & 34,003 & 75,124 & \\
- Siak & 160,249 & 411,633 & \\
- Indragiri Hilir & 107,373 & & 225,900 & \\
- Pekanbaru & 3,952 & & 2,687 & \\
State-Owned Plantations & $\mathbf{7 9 , 5 4 6}$ & $(4 \%)$ & $\mathbf{3 2 0 , 7 7 9}$ & $(5 \%)$ \\
Private Plantations & $\mathbf{9 7 3 , 5 0 9}$ & $(43 \%)$ & $\mathbf{3 , 5 5 2 , 2 6 6}$ & $(50 \%)$ \\
Total & $\mathbf{2 , 2 5 8 , 5 5 3}$ & $(100 \%)$ & $\mathbf{7 , 0 4 7 , 2 2 1}$ & $(100 \%)$ \\
\hline
\end{tabular}

Source: Plantation Service of Riau Province (2012) 
Oil palm cultivation is proven to contribute to increasing the welfare of farmers in rural areas (Syahza 2009), but differences exist among the oil palm farmers in their business' achievements. Some oil palm farmers have successful plantations, but some do not. From the entrepreneurship perspective, the entrepreneurship characteristics of the farmers will affect their business' performance and achievement (Kalio and Kola, and Kupiainen in McElwee 2006; and Sriram et al. 2007). The characteristics of an entrepreneur give farmers who posess them the competitive advantage over farmers who do not.

This paper studied the oil palm farmers in running their farms from the entrepreneurial perspective. The questions proposed by this research are: What are the entrepreneurship characteristics of oil palm farmers? And how do these entrepreneurship characteristics differentiate the oil palm farmers' business achievements? The objectives of this research were to identify the entrepreneurial characteristics of oil palm farmers and to know how such entrepreneurship characteristics differentiate the oil palm farmers' business achievements.

\section{Oil Palm Farmers as Entrepreneurs}

Glancey et al. (1998) said that a craft entrepreneur was characterized by a low level of education and a lack of managerial experience, who was reluctant to use outside help, and who was reactive to changes in market demand rather than proactive in generating new business. Craft entrepreneurs are similar to farmers' characteristics. The oil palm farmer also does not need a high level of education, but does need the farming skills to run the oil palm plantation. Agricultural production of oil palms and Crude Palm Oil
(CPO), are export oriented commodities of Riau province. The price of oil palms' Fresh Fruit Bunches (FFB) at the farmers' level depends on CPO's international price. The entrepreneur plays a role in this situation where the farmer's dependency on CPO's international price is high. McElwee et al. (2006) said that farmers operated in an arena evidenced by the shifts from a subsidised environment to a market-driven environment. As an entrepreneur, oil palm farmers should not put themselves in an uncomfortable situation that endangers their plantation business.

The empirical studies done by Carter (2003) suggested that structural diversifiers were more entrepreneurial than monoactive farmers concentrating on primary production. The same results were in Vesala and Peura's (2003) study; they compared monoactive farmers, structural diversifiers, and non-farm small business owners from the perspective of entrepreneurial role expectations. They found the monoactive farmers were more hesitant to identify themselves as entrepreneurs than the structural diversifiers and the non-farm small business owners were. The spectrum of the 'farmer-entrepreneur' by Carter is used in this paper which tries to discover the entrepreneurial identity of oil palm farmers by identifying entrepreneurial characteristics within them.

\section{Conceptual Framework}

From a study of the available literature, the authors conducted a conceptual framework of entrepreneurship characteristics for oil palm farmers. A conceptual framework is research guidance to help choose places, people, or events that will maximize the opportunities to discover variations among concepts, and to density categories in terms of their properties and dimensions. There were 
Figure 2. Research Conceptual Framework

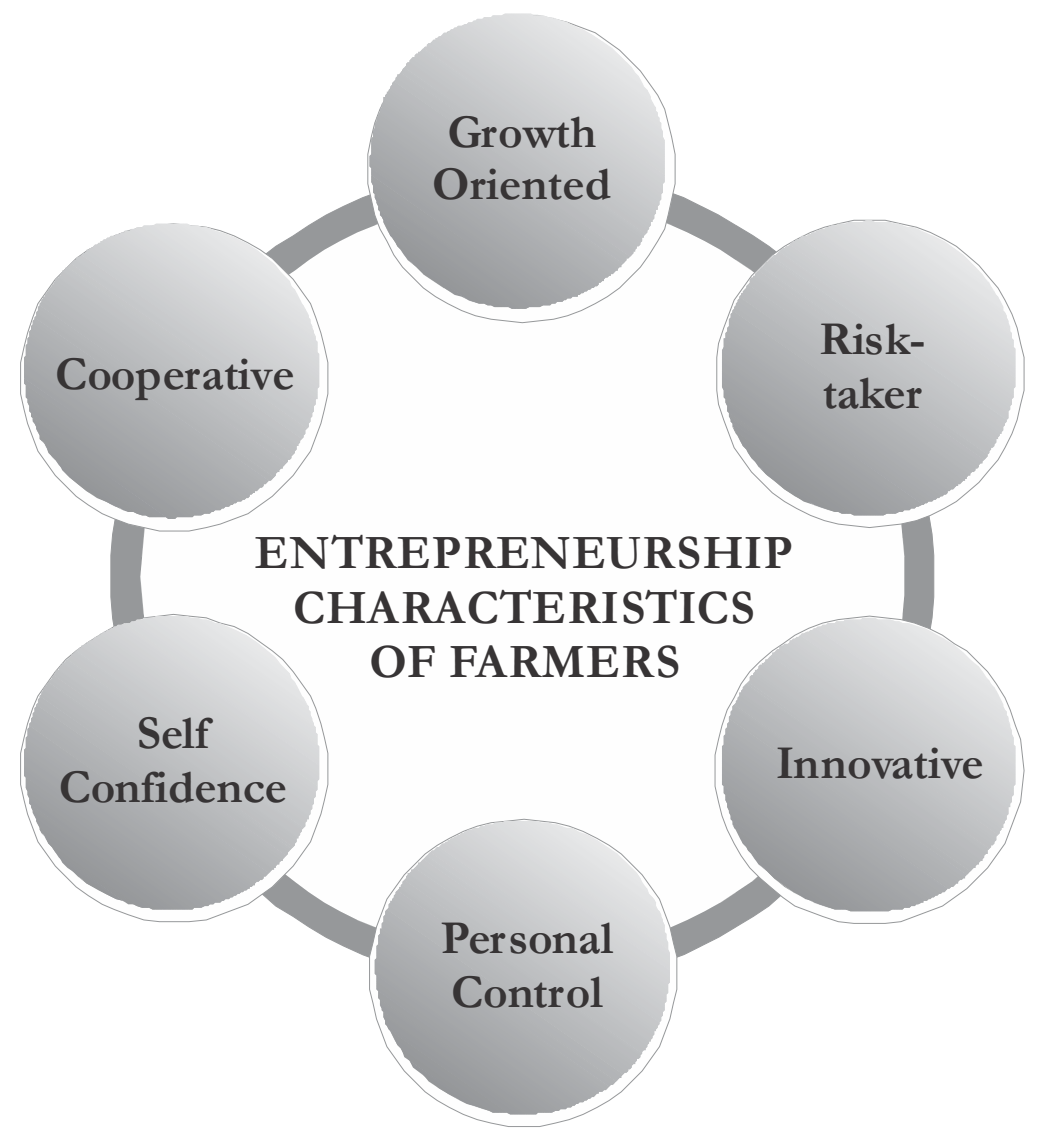

six entrepreneurship characteristics found from the literature that needed to be studied in this paper: Growth oriented, risk-taker, innovativeness, sense of personal control, self confidence, and cooperative. These caracteristics will be looked at in the oil palm farmers who run plantation businesses. The conceptual framework of the six entrepreneurial characteristics is displayed in Figure 2 .

Growth-oriented. A farmer, as an entrepreneur, has a tendency to maximize benefits by land expansion, farm activities and expanding the farm. Farmers, as entrepreneurs, are not satisfied with simply earning their own living, but are expected to aim for growth (Vesala et al. 2007; McElwee 2006; Kallio and Kola, and Hanf and Muller in McElwee 2006; and, Johnson, 2001).

Risk-taker. A farmer, as an entrepreneur, realizes the risks that exist in the process of expanding the farm, and they maximize their profit by bearing the possibility of failure as the risk (Vesala et al. 2007; McElwee 2006; Johnson 2001; and Koh 1996).

Innovativeness. Innovative entrepreneurs do search for, develop and try new products, markets, and methods (Vesala et al. 2007; McElwee 2006; Johnson 2001; Koh 1996; and Bonet et al. 2011).

Sense of personal control. Farmers, as the owners of the farms, are ready to work hard and be accountable for their self-directed 
decisions in their business activities (Vesala et al. 2007; McElwee 2006; Johnson 2001; and Bonet et al. 2011).

Self confidence. Farmers who believe in what they are doing have a greater advantage. Belief in ones success is a psychological requirement for persistence in pursuit of success in general, and it has also been included in descriptions of entrepreneurial motivation (Vesala et al. 2007; Kallio and Kola in McElwee 2006; Johnson 2001; and Bonet et al. 2011).

Cooperative. From the pilot research, the authors assumed the farmers' ability to get on with other people, as cooperation with other farmers and plantation companies, or agencies will help farmers in developing their oil palm plantations. This entrepreneurship characteristic is also found in papers by Kallio and Kola in McElwee (2006) and Bonet et al. (2011).

\section{Research Methodology}

The qualitative method was suitable for this research because the authors needed indepth information about entrepreneurial characteristics directly from the farmers as the participants, and also environmental conditions. The suitable method was the grounded theory (Strauss and Corbin, 1998), a methodology in which the authors attempted to derive a general, abstract theory of a process, action, or interaction grounded in the views of the participants in the study.

The sampling method used in the field was theoretical sampling. This is data gathering driven by concepts derived from the evolving theory and based on the concept of making comparisons, whose purpose is to go to places, people, or events that will maximize opportunities to discover variations among the data and to add the density of the

\section{Figure 3. Illustration of Grounded Theory Analysis Used for the Research}

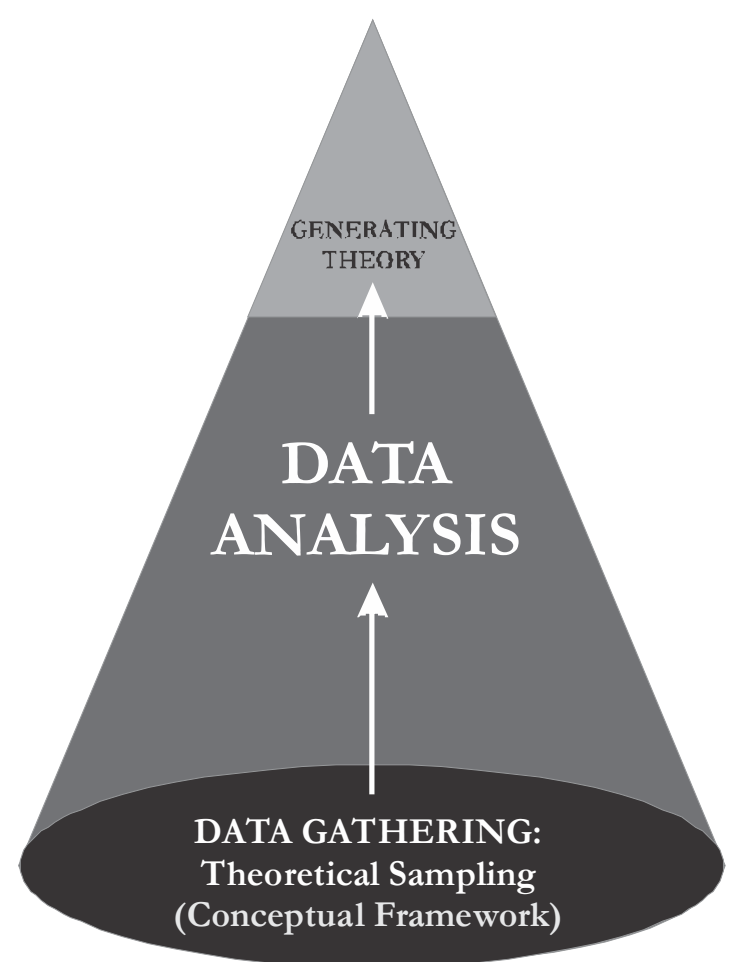


data's properties and dimensions (Strauss and Corbin, 1998). The grounded theory used for the research is illustrated in Figure 3.

\section{Data Collection}

Primary data were obtained through indepth interviews, observations, field notes, and documentation. Through those methods the authors could obtain the information of entrepreneurial characteristics among the farmers. To complete the desired information, the authors also interviewed community leaders and officials from the area of the research site. In the pilot research, the authors gathered information from the experts on oil palm plantations in Riau. Information gathered from them was also the data for this research. Their role in this research was as informants, and to allow us to cross-check the information gathered from the interviews, field notes, and observations with them.

Data gathering was done in the Kampar and Siak areas, which are both growth areas for oil palm plantations in the Province of Riau. In both areas there are oil palm plasma farmers with state-owned and privatelyowned enterprise as their core enterprises, moreover there are people who are also plasma farmers who cultivate oil palm independently. From the land ownership of oil palm plantations in the Kampar and Siak areas the samples represent the data we needed for this research.

\section{Profile of Oil Palm Farmers}

The subject of this research is the oil palm farmers in Riau; they are transmigrant families from the program in the 1980s, and called plasma farmers. The program namely The People's Core Plantation, well known as Perkebunan Inti Rakyat (PIR), it was carried out by the Indonesian government, with assis- tance from some plantation companies, in an effort to redistribute the populations of densely populated areas, with few employment opportunities, to less crowded areas with labour shortages. The plasma farmers in Riau were originally from Java, and also from Bali. Based on the pilot research, plasma farmers who had a minimum of 2 ha had the opportunity to develop their plantation businesses. The authors set the criteria for the respondents needed for the research as oil palm farmers who had at least a 2 ha area of oil palm plantation, either plasma or as a selfhelp area.

\section{Instrument of Data Collection}

In gathering the research data, the authors preferred semi-structured interviews guided by primary questions to dig out the information about the entrepreneurial characteristics of the farmers. Below are the primary questions the palm oil farmers were asked:

a. Questions for identifying the "growth-oriented" characteristic: How did you start to farm oil palms, and support yourself until your farming activities had established? Are you satisfied with the results obtained from your farm? Do you have any plans to develop your business? What is required to reach the target of your plans?

b. Questions for identifying the "innovativeness" characteristic: Do you do things in different ways from other farmers to maximize your profit? What changes have you made to maximize your business' profit? Which of your ideas have been realized for your business' development? And which ideas have not been realized yet? How do you react when encountering obstacles and difficulties in managing and marketing your product? 
c. Questions for identifying the "self-confidence" characteristic: When you started the business, how confident were you that it would be a success? What constraints and difficulties make you pessimistic about it being a success?

d. Questions for identifying the "sense of personal control" characteristic: What is your role in the decision making process relating to the success of your business? Do you have full control of the decision making process related to your business activities? With the ability and skills that you have, can you make your business grow and become more successful?

e. Questions for identifying the "risk-taker" characteristic: What risky decisions do you ever take when doing business? Under what circumstances do you dare to make a risky decision? Faced with making a decision that would be a risk, but also beneficial in developing your business, do you dare to make and take the risky decision?

f. Questions for identifying the "cooperative" characteristic: In what form and with whom are you working to develop your business? Does cooperation assist you to make your business grow?

\section{Data Processing and Analysis}

\section{Categorizing Oil Palm Farmers}

In total there were thirteen oil palm farmers as the respondents for the research. In preliminary analysis of the interviews and observation results 'on-site' the authors identified two categories of oil palm farmers, divided by how they ran their farm businesses and their diversifications: a. The first category was labeled as "Conventional farmers" who run their plantations in the conventional way. Their farms' business was purely agricultural, where they can earn an income to maintain their viability. This category was identified by their ownership of less than 20 ha of oil palms, and the only business they had was oil palm cultivation. There were 5 respondents in this category.

b. The second category was labeled as "Diversified farmers" who were the outstanding farmers at the research sites. This category was identified by their diversification of their farms' and non-farms' businesses. They were growing rapidly compared to the other farmers and currently have an average oil palm plantation area larger than 20 ha. There were 8 respondents in this category.

Both categories of farmers were adopted from previous research done by Vesala et al. (2007); Vesala and Peura (2002); and Carter (2003). They studied the entrepreneurial characteristics of farmers in Europe. This divide enabled the authors to identify the entrepreneurial characteristics of the farmers who ran their oil palm plantations successfully and why these characteristics make a difference between two categories of farmers.

There were three steps to the data analysis of the grounded theory, namely open coding, axial coding and selective coding.

\section{Open Coding Analysis}

The in-depth interviews with the farmers were examined, and any indications found were coded then the codes were compiled into groups. Each statement was also coded by which category of farmer made it, the conventional or the diversified farmer. 
Gadjah Mada International Journal of Business - September-December, Vol. 17, No.3, 2015

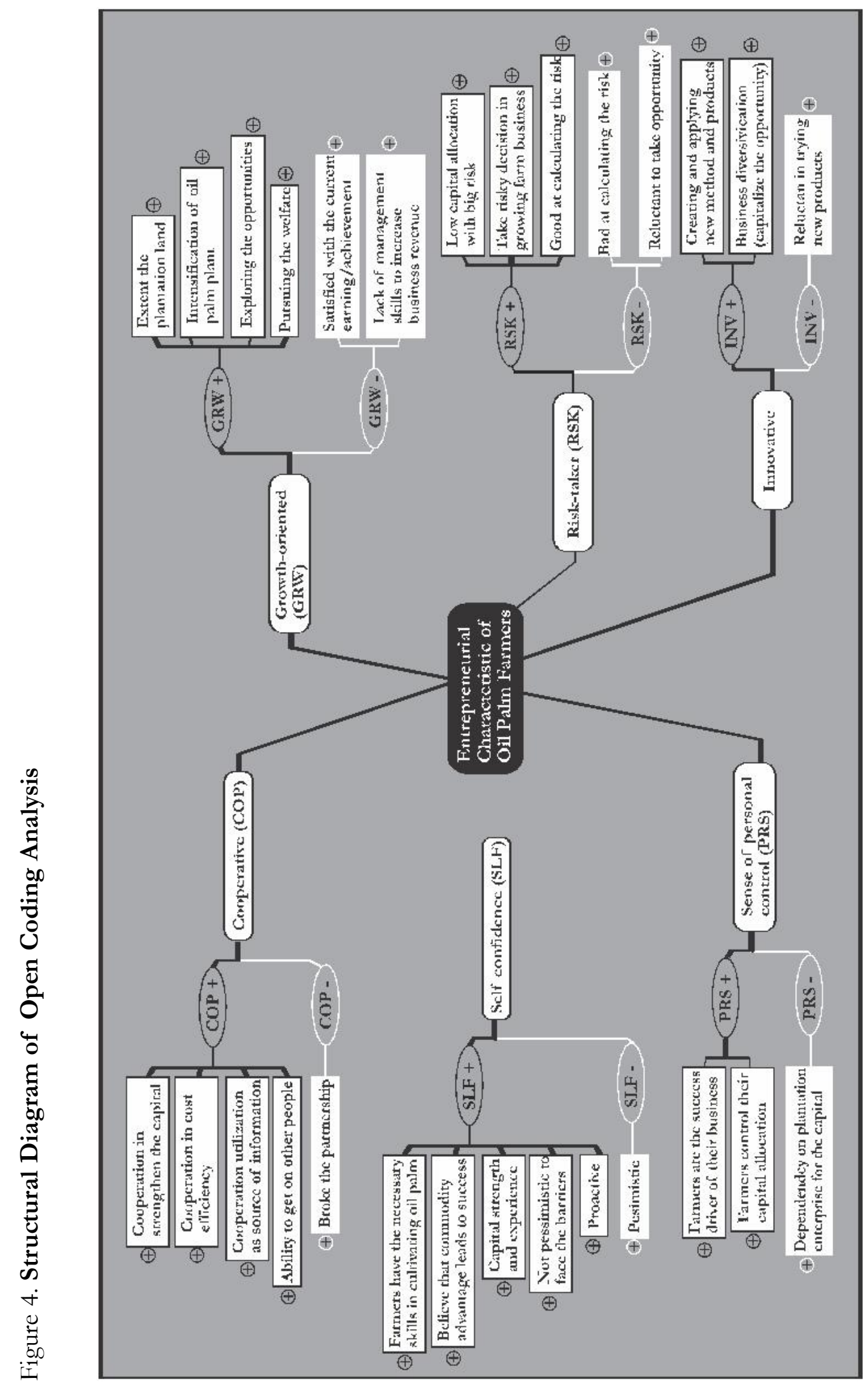


The data was displayed in a structural diagram, as well as being presented in Figure 4 , to facilitate the analysis process. In this diagram all the gathered data are compiled into groups which represented their entrepreneurial characteristic properties. There were six groups of entrepreneurial characteristics constructed in the conceptual framework. Each characteristic was divided into two subgroups, one filled with positive statements that tended to have entrepreneurial characteristics, and another filled with negative statements. Later, the statements that had the same properties and dimensions were compiled into a subcategory. This subcategory represented the indications of entrepreneurial characteristics of the oil palm farmers.

\section{Axial Coding Analysis}

Axial coding is the act of relating categories to subcategories along the lines of their properties and dimensions. Axial coding presented six figures that represented each entrepreneurial characteristic. The figures from the axial coding step conclude the link between the entrepreneurial characteristics (category) and concepts (subcategory) discovered from the open coding. Each figure describes the concepts indicated by the characteristic of entrepreneurship within the oil palm

Figure 5. Axial Coding Output for Growth Oriented Characteristic




farmers. It shows the position of the concept, as an indicator of the entrepreneurial characteristic of the oil palm farmers, and in which group the farmers fall. The outputs of axial coding analysis are presented in Figures 5-10.

Figure 5 shows that both groups were inclined to be growth oriented. But the group of diversified farmers had more indications that described them, and were more inclined to be growth oriented than the conventional farmers. The box of negative indications showed the conventional farmers were less growth oriented. For the risk-taker characteristic, the indications of bad risk calculations and reluctance to take risky decisions showed the conventional farmers were less inclined to be risk-takers compared to the diversified farmers. The difference between the conven- tional and diversified farmers as risk-takers can be seen in Figure 6.

From Figure 7, the diversified farmers were more inclined to beinnovative compared to the conventional farmers, who were reluctant to try new cultivation ideas. And also Figure 8 showed the diversified farmers were more inclined have the personal control characteristics, whereas the conventional farmers indicated they depended on the plantation agencies for capital.

The indications of pessimism shown in Figure 9 represent the conventional farmers. It shows that they have little self confidence compared to the diversified farmers. The last entrepreneurial characteristic, cooperation, is presented in Figure 10. The result of the axial coding shows both farmers' groups have positive indications for the cooperative characteristic.

Figure 6. Axial Coding Output for Risk-taker Characteristic

\begin{tabular}{|c|c|c|c|}
\hline \multicolumn{4}{|c|}{ Inclined as Risk-taker } \\
\hline & - Independently seek the & - Low capital allocation with & \multirow{4}{*}{  } \\
\hline & $\begin{array}{l}\text { - Take risky decision in } \\
\text { growingfarm business }\end{array}$ & $\begin{array}{l}\text { - Take risky decision in } \\
\text { growing farm busines }\end{array}$ & \\
\hline & $\begin{array}{l}\text { - Good risk calculation in } \\
\text { farming activities }\end{array}$ & $\begin{array}{l}\text { - Good risk calculation in } \\
\text { spending funds }\end{array}$ & \\
\hline & $\begin{array}{l}\text { - Bad risk calculation } \\
\text { - Reluctant to take risky } \\
\text { oportunity }\end{array}$ & $\begin{array}{l}\text { - Bad decision making with } \\
\text { high risk }\end{array}$ & \\
\hline 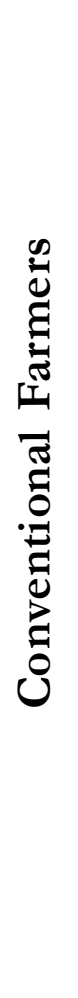 & Not In & s Risk-taker & \\
\hline
\end{tabular}


Figure 7. Axial Coding Output for Innovativeness Characteristic

\begin{tabular}{|c|c|c|c|}
\hline 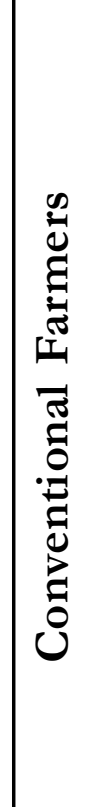 & $\begin{array}{l}\text { - Reluctant in applying new } \\
\text { cultivating products } \\
\text { Not Incli }\end{array}$ & $\begin{array}{l}\text { Innovative } \\
\text { - Creating and applying new } \\
\text { method and applying new } \\
\text { cultivating products } \\
\text { - A visionary in business } \\
\text { diversification }\end{array}$ & 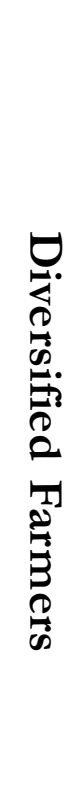 \\
\hline
\end{tabular}

Figure 8. Axial Coding Output for Personal Control Characteristic

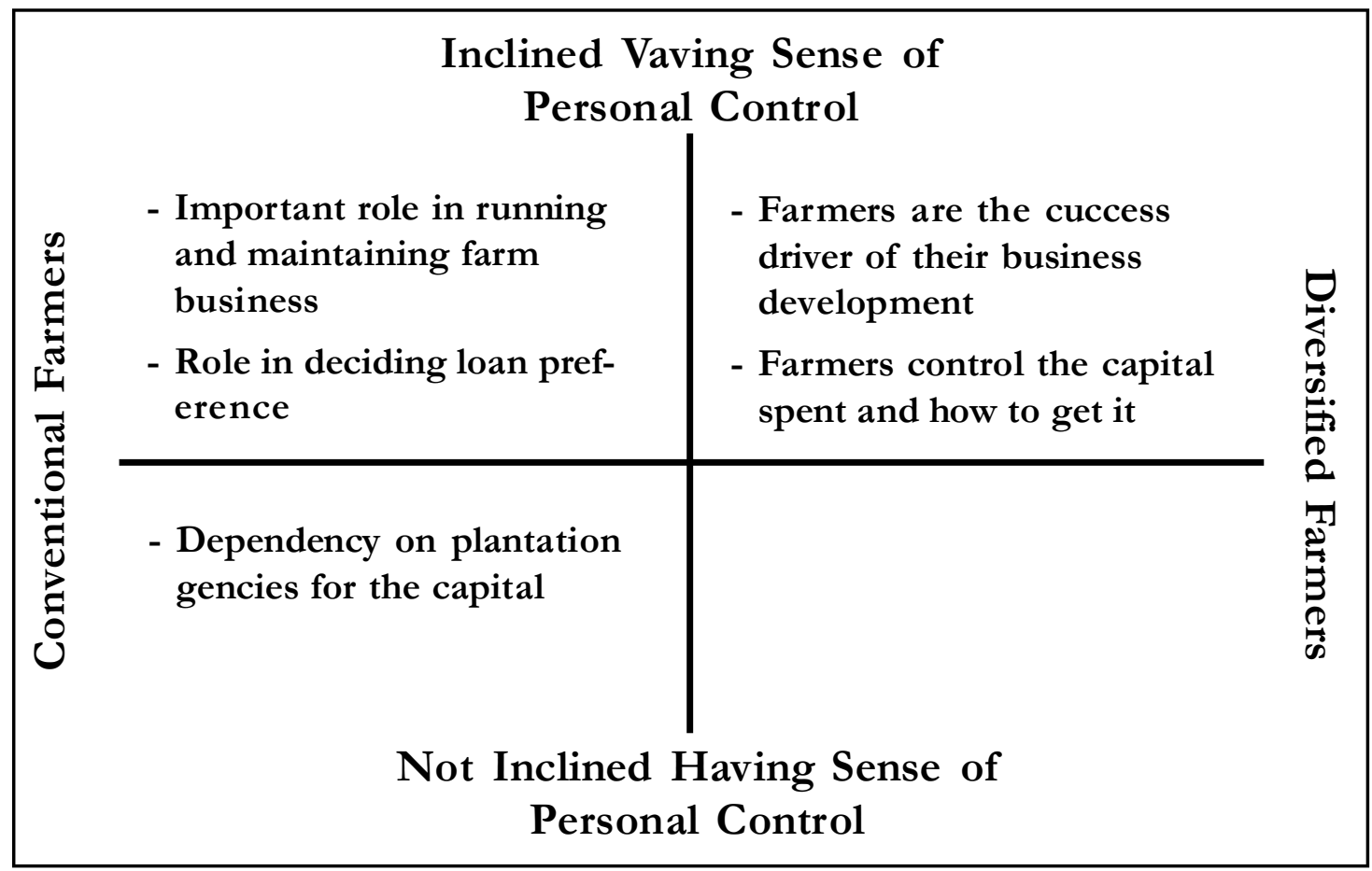


Figure 9. Axial Coding Output for Self Confidence Characteristic

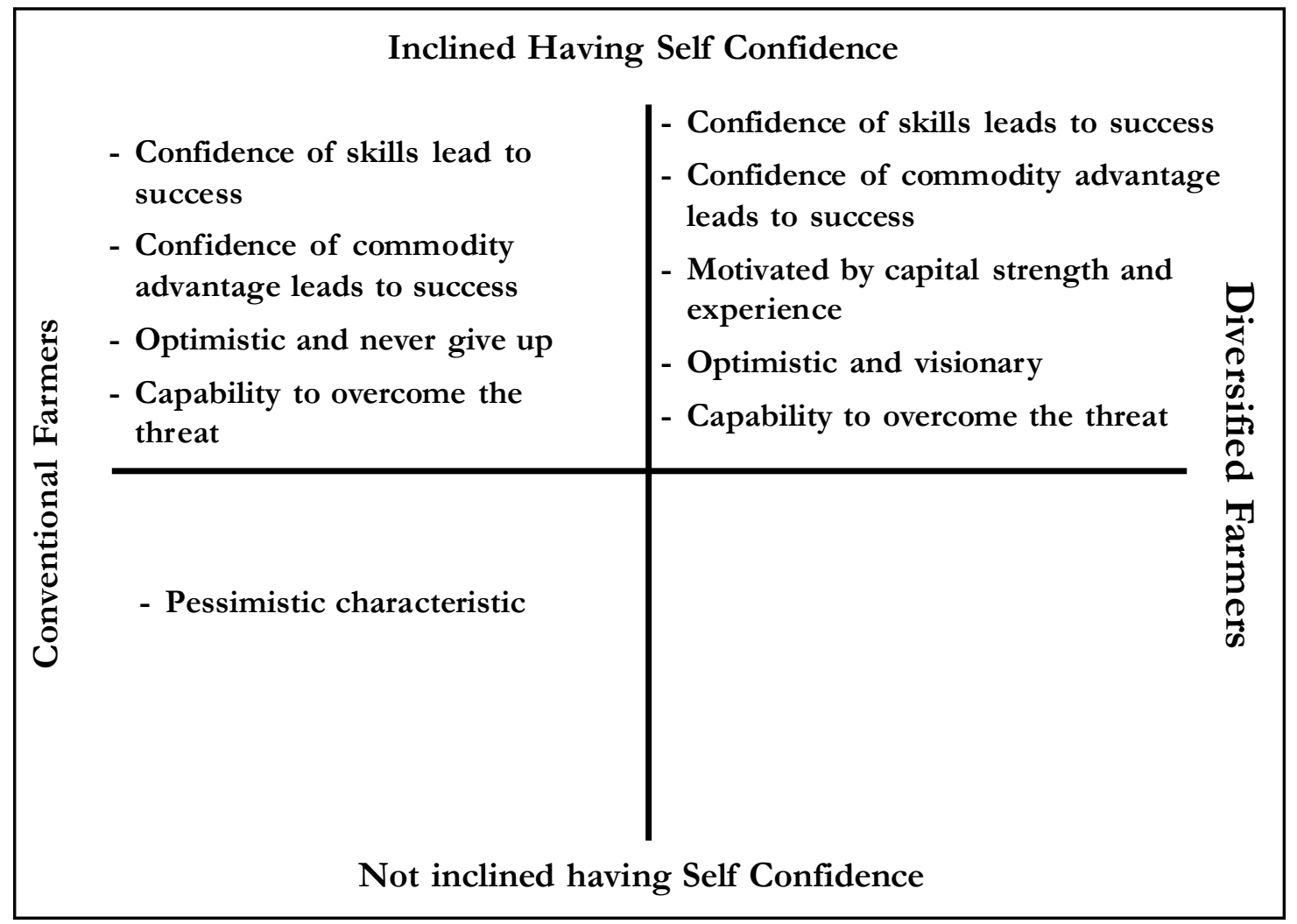

Figure 10. Axial Coding Output for Cooperative Characteristic

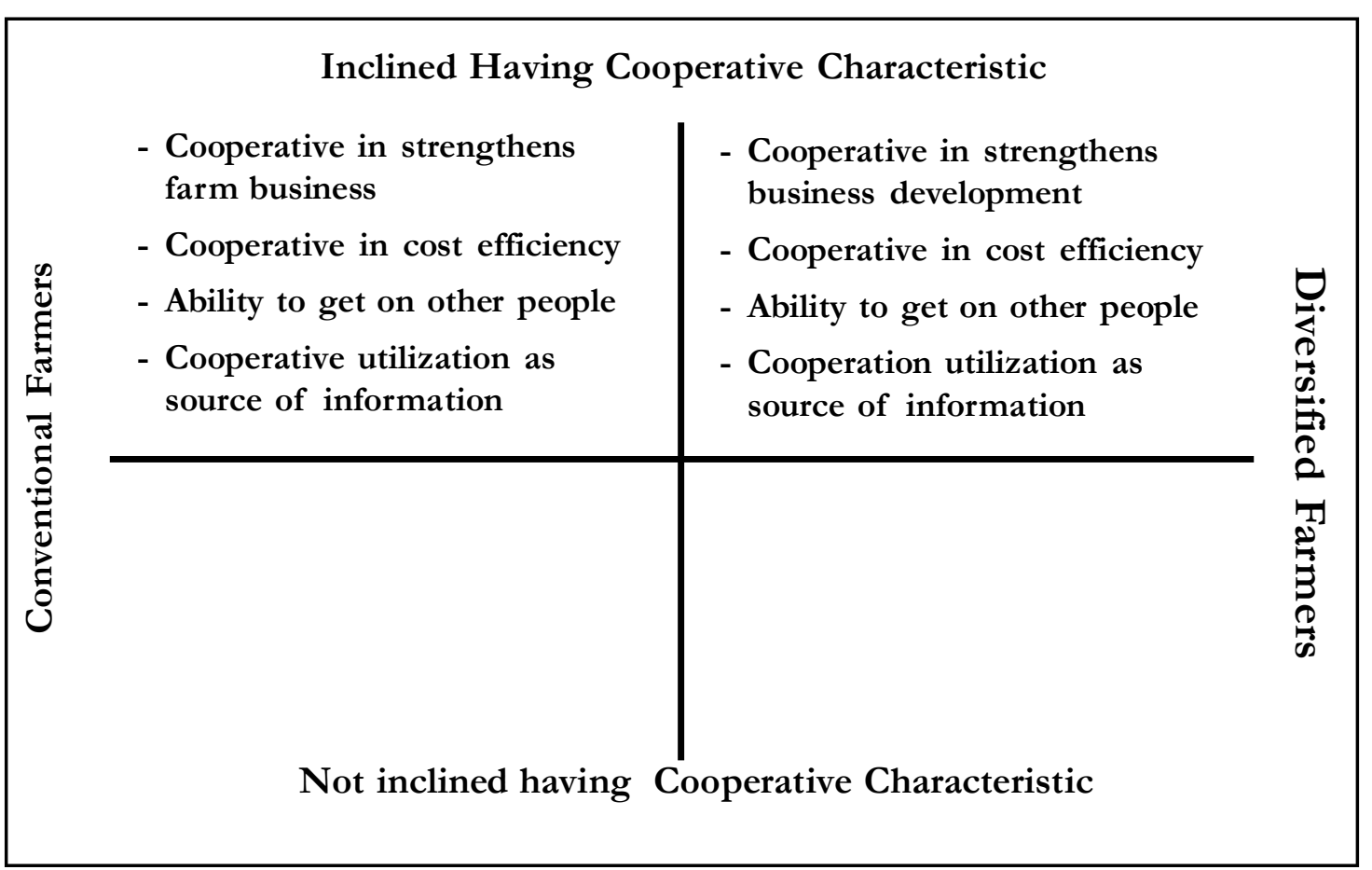




\section{Selective Coding Analysis}

Selective coding analyzed the phenomenon by combining the concept discovered in open coding and the connections with the categories in the axial coding's figures. This step is generalizing all the data from the first two coding steps into a theory. The output of this step is our research findings in the form of a theory.

\section{a. Characteristic of growth oriented}

The authors suggest that diversified farmers are more inclined have growth oriented characteristics compared to conventional farmers. Diversified farmers tend to enrich themselves by having a lot of assets. These assets are in the form of large plantations that produce a lot of money.

The diversified farmers are inclined to develop their plantations' areas. A succesful farmer in one village owns 70 ha of oil palm plantation; at first he had only 2 ha. Other diversified farmers in this study own more than 30 ha. Even though there is no vacant land to develop plantations they expand their plantations into other districts. Diversified farmers also identify themselves as opportunity seekers. The farmers also do business as intermediate traders, they capitalize on the opportunity to collect and sell FFB from other self-help oil palm plantation farmers. Prior to 1997 the diversified farmers sought capital from the banks in order to expand their palm oil plantation businesses, when other farmers were afraid to borrow money from banks. The diversified farmers used the land certificate for their first 2 ha plantations as collateral to borrow money from bank to use as capital to expand their business.

\section{b. Characteristic of risk-taker}

The authors suggest that the diversified farmers are inclined to be risk-takers compared to the conventional farmers. It can be seen that the diversified farmers have a lot of experience in taking risks, but are also able to reduce the uncertainty, all of which indicates that they are risk-takers.

The diversified farmers choose to plant uncertified oil palm seeds in their plantations, even though the government suggests only certified oil palm seeds be planted. They prefer to plant the uncertified seeds because they are easier to obtain, and do not require any administrative process, which makes them cheaper than the certified seeds. In the past they did experience crop failure because of bad quality (uncertified) seeds, but now they can differentiate between good and bad quality uncertified seeds, and so reduce the probability of crop failures.

\section{c. Characteristic of innovativeness}

Their business diversification indicated that diversified farmers were more inclined to have innovative characteristics compared to the conventional farmers. In fact, the authors only identified two concepts of innovativeness from the open coding step. The innovativeness of the diversified farmers was seen by how they created new income sources (businesses), and created and applied new methods and products in running their plantations.

There were some methods invented by the farmers to deal with pests and fires, such as using old clothes to repel boars, building simple fences around each palm oil plant to protect it from boars, and they dug large trenches around the area to prevent elephants entering, and also to act as fire breaks. To maintain their plantations, the farmers collect and pile up the oil palm fronds that fall to the land above the bushes outside the plants' seedbed. It obstructs the bushes to grow and reduces the cost of clearing the 
bushes. All of these inventions come from experience and local knowledge. Diversified farmers are not afraid to try and apply new fertilizer types and other new methods of, or aids to, cultivation, in order to gain higher yields for less cost. This differs with the conventional farmers who only use the same old methods because they are known and easier.

Diversified farmers also do business as intermediate traders; they capitalize on the opportunity to collect and sell FFB from the self-help oil palm plantations. Not only do they try businesses related to palm oil, but they realise that the villagers need to fulfill their daily needs so the diversified farmers operate stores or shops in the villages.

\section{d. Characteristic of personal control sense}

With their ability to run successful farms, take important strategic decisions and posess the capital strength to reduce their dependency on others, all these indicate that the diversified farmers have a greater sense of personal control than the conventional farmers.

Farmers make decisions regarding their farms' business. In the field, the authors found that the farmers had planted bad oil palm seeds, which had low productivity. So the farmers decided to replace the plants with good seeds. They knew it would cost a lot to replace the plants, but the effort would be worth the profit gained in the future. The characteristics of personal control can be seen in how the farmers run their self-help oil palm plantations. Farmers can decide to delay harvesting, fertilizing, and other production activities, based on their financial state. From their sales of the FFB of other self-help plantation farmers, they receive an income to keep them ticking over until their own crop is ready for harvesting and sale. Also, the farmer himself is the one who de- cides on the seedlings for his plantation. All the decisions regarding investing, planting, maintenance, fertilization, harvesting, marketing, and other production activities for his plantation are entirely down to the farmers.

Meanwhile, the authors found that the conventional farmers depended on outside agencies for their capital. They rely on funds from their core companies, as an example, for plantation revitalization after the original plants' productivity is over they rely on grants from the core company of up to 80 million IDR for their 2 ha plantation. Conventional farmers admit that they prefer this plasma system rather than a self-help plantation because it alleviates the procurement of capital.

\section{e. Characteristic of self confidence}

The authors suggest that the diversified farmers are more confident compared to the conventional farmers. This can be seen from their vision, and ability to realize their vision. $\mathrm{Di}$ versified farmers believe in their capabilities to run their businesses successfully.

There are some reasons why farmers choose to cultivate self-help oil palm plantations: (1) They look a better prospect for having success with farming oil palms; (2) most people around cultivate oil palms; and, (3) oil palm has superior production costs and sales compared to rubber. Farmers have the income to repay loans and it makes them confident of success. Farmers have the motivation to rise from any failures. Fires and pest attacks are obstacles for the self-help plantation, and farm activities stop when there is no capital for plantation revitalitation. They experienced their young oil palm trees being eaten by wild boar, and it took them almost a year before they could replace the damaged crops because they did not have the necessary capital. However they admit that the 
obstacles to cultivating oil palms do not make them give up or be pessimistic.

\section{f. Characteristic of cooperative}

The authors suggest that oil palm farmers have cooperative characteristics, and there is no indication that this cooperativeness influences any distinction between diversified farmers and conventional farmers. The two categories of farmers do cooperate, but for different purposes. The authors could not say one category of farmer was more cooperative, except if one category showed more or less indication than another as displayed by Figure 10.

Both the diversified and conventional farmers in this study were members of cooperatives. These institutions have a role in the farming activities of the villages, such as pest control, FFB marketing, fertilizer supplies, building and maintaining the members' plantations main roads, even helping with the procurement of capital to develop their oil palm plantations. The existence of these cooperatives also makes the farmers more effective and efficient in managing their plantation businesses.

\section{Discussion}

The research suggested that the oil palm farmers had the six proposed entrepreneurship characteristics, they were growth oriented, risk-takers, innovative, had a sense of personal control, self confidence, and cooperative. The entrepreneurial characteristics of the oil palm farmers could be seen from the characteristics' indications of how they ran their businesses. Entrepreneurship characteristics were found in how the farmers made decisions, the motivation to develop their businesses, seek opportunities, their persuasiveness, increasing their business' revenues, and for some farmers it could be seen from their business diversification. The results define that the two groups of oil palm farmers are different in their entrepreneurship, the diversified farmers are more inclined to be entrepreneurs compared to the conventional farmers. It can be seen that five of the six proposed entrepreneurship characteristics differentiate the diversified farmers from the conventional farmers. These five characteristics are the growth orientation, risk-taking, innovativeness, sense of personal control, and self confidence.

This result is similar to the paper about entrepreneurial characteristics done by Vesala et al. (2007) where the portfolio farmers, as the sample, perceived themselves as growthoriented, risk-takers, innovative, optimistic, and having more personal control compared to the conventional farmers. However, the similarity of the results of these 2 researches did not mean that diversified oil palm farmers in Riau have the same entrepreneurship capability levels as Vesala et al.'s portfolio farmers in Finland. Since the same entrepreneurship characteristics were found from different research objects (different geographical areas and commodity types), this result could enrich the knowledge about the entrepreneurship characteristics and entrepreneurial identity of farmers.

In this research, the authors put the characteristic of cooperation to the oil palm farmers of Riau as an object. Cooperation becomes a concept for most Indonesian people to attain goals together. This research found that oil palm farmers have the cooperative characteristic, but there is no indication to show that cooperativeness differentiates the entrepreneurship of the oil palm farmers based on their achievement. Both categories, conventional and diversified, uti- 
lize this cooperation to maintain their activities on their farms.

\section{Conclusions}

Oil palm farmers are identified as having the entrepreneurial characteristics of being growth oriented, risk-takers, innovative, sense of personal control, self confidence, and cooperative. The research analyzed that there were different business achievements among the oil palm farmers. The authors separated the palm oil farmers based on their business' achievements into two categories; they were the diversified farmers and the conventional farmers. The diversified farmers were identified by their business' diversifications into farm and non-farm schemes. The conventional farmers' businesses were purely focused on agricultural activities where they could earn an income to maintain their viability. The research found that diversified farmers were more inclined to be entrepreneurs compared to the conventional farmers. This can be seen from the five identified entrepreneurial characteristics which differentiated the diversified farmers from the conventional farmers. The five characteristics are that they are growth oriented, risk-takers, innovative, with a sense of personal control, and self confident. The characteristic of cooperativeness was the only one that does not differentiate the entrepreneurship between the 2 groups.

\section{References}

Bonet, F. P., C. R. Armengot, and M. A. Galindo Martin. 2011. Entrepreneurial success and human resources. International Journal of Manpower 32 (1): 68-80.

Carter, S. 2003. Entrepreneurship in the farm sector: Indigenous growth for rural areas. In Proceedings of 2nd Nordic Workshop on Entrepreneurship in Regional Food Production Bodø (5 - 6 May) (Entrepreneurship in Regional Food Production: 22-47), Nordlandsforskning.

Central Bureau of Statistics of Riau Province. 2012. Rian in Figures 2012. Pekanbaru: Central Bureau of Statistics of Riau Province.

Coordinating Ministry of Economic Affairs. 2011. Masterplan: Percepatan dan Perluasan Pembangunan Ekonomi Indonesia. Jakarta: Coordinating Ministry of Economic Affairs.

Glancey, K., M. Greig, and M. Pettigrew. 1998. Entrepreneurial dynamics in small business service firms. International Journal of Entrepreneurial Behaviour and Research 4 (3): 249-268.

Johnson, D. 2001. What is innovation and leadership? Lesson for larger organizations. Industrial and Commercial Training 33 (4): 135-140.

Koh, H. C. 1996. Testing hypotheses of entrepreneurial characteristics: A study of Hong Kong MBA students. Journal of Managerial Psychology 11 (3): 12-25.

McElwee, G. 2006. Farmers as entrepreneurs: Developing competitive skills. Journal of Developmental Entrepreneurship 11 (3): 187-206.

McElwee, G., A. Anderson, and K. M. Vesala. 2006. The strategic farmer: A cheese producer with cold feet? Journal of Business Strategy 27 (0): 65-72.

Plantation Service of Riau Province. 2012. Statistik Perkebunan Provinsi Riau 2011. Pekanbaru: Plantation Service of Riau Province. 
Sriram, V., T. Mersha, and L. Herron. 2007. Drivers of urban entrepreneurship: An integrative model. International Journal of Entrepreneurial Behaviour and Research 13 (4): 235-251, Emerald Group.

Strauss, A., and J. Corbin. 1998. Basics of Qualitative Research: Tecbniques and Procedures for Developing Grounded Theory (2nd ed.). Thousand Oaks-London-New Delhi: Sage Publications, Inc.

Syahza, A. 2009. Perumusan model pengentasan kemiskinan melalui pemetaan kelembagaan ekonomi berbasis agribisnis di Propinsi Riau. Penelitian Strategis Nasional DP2M Direktorat Jenderal Pendidikan Tinggi Departemen Pendidikan Nasional. Jakarta.

Syahza, A. 2012. Institutional arrangements in the oil palm sector: Effort to spur economic growth in rural areas. International Research Journal of Business Studies 4 (3): 171-188.

Vesala, K.M., and J. Peura. 2003. Farmers with additional business, mono-active farmers and non-farm rural small business owners in comparison from the viewpoint of entrepreneurial role expectations. Entrepreneurship in Regional Food Production: Proceedings of 2nd Nordic Workshop on Entrepreneurship in Regional Food Production. Bodø (5-6 May): 22 - 47. Nordlandsforskning.

Vesala, K.M., J. Peura, and G. McElwee. 2007. The split entrepreneurial identity of the farmer. Journal of Small Business and Enterprise Development 14 (1): 48 - 63.11. 
